\title{
An Investigation on the Corporate Image Perception for Sports Clubs
}

\author{
Mehmet Kargün \\ School of Physical Education and Sports, Tokat Gaziosmanpaşa University, Turkey
}

Copyright $(2018$ by authors, all rights reserved. Authors agree that this article remains permanently open access under the terms of the Creative Commons Attribution License 4.0 International License

\begin{abstract}
The purpose of this study is to investigate the perception of institutional image as regards to sports clubs. The descriptive scanning model was used in the study. A survey (questionnaire) was applied, therefore, as the data collection method in the research. The data analysis for the study was completed using the SPSS 16 package program. The descriptive statistics, T-test, and Anova tests were executed for analyzing the data obtained. The corporate image perception for sports clubs has been examined in the study. According to the results of the research obtained, the perception about sports clubs does not cause significant changes in terms of the demographic characteristics of individuals. A conclusion which argues that sports clubs have been beneficial for society causes an increase for the sense of corporate image.
\end{abstract}

Keywords Image, Corporate Image, Sports Clubs

\section{Introduction}

Economies and companies of a globalizing world are in a position of steady competition. The ability of companies to maintain their existence depends heavily on their having different features compared to other companies. The institutional image of the companies, meanwhile, appears as a factor by which they shall be able to reflect their own differences. Companies create their customer groups thanks to the sense of corporate image and thus they are separated from their competitors.

Today's companies have been struggling constantly to create their own institutional image using various visual elements and advertisements. That the image of a company, in this context, is to be directed positively using these factors is very important in terms of both for increasing the sales of companies and providing customer loyalty. Companies that assure customer loyalty, on the other hand, shall take their existence under warranty in the long term. All this shows that the corporate image is the unique tool that keeps companies alive.

\section{Corporate Image}

Today's conditions have created a market where many companies have been competing continually. The companies that desire to survive in such a competitive environment need to have a number of distinctive features compared to other companies. In this regard, typical characteristics of companies, which shall to be different from other companies, reveal the corporate image of a company.

Various definitions have been made, meanwhile, in the literature regarding the corporate image. The corporate image is defined, in one of these definitions, as "a factor to be constituted between employees of a company and in the eyes of consumers in the market where a company gives services, and also a factor that imposes a meaning and value on a company" [9]. The corporate image for a firm is defined, in another definition, as "the impressions of the public, the customers or the consumers, and the institutions that a firm works jointly [7].

The corporate image is a kind of reflection of an institution or establishment on society where it has been maintaining its existence. That is, it means how a company is evaluated by society and its affiliates. In this regard, companies can get some certain knowledge only by observing the society which shall make accurate evaluations about them [1]. The corporate image is defined, in another definition as, "a mixture of the image of a company that it tries to transmit to a society and the evaluations collected about a company from individuals in society" [10].

The institutional image means "the messages of people about business activities of companies and it is evaluated by customers, consumers or the ones who prefer their products" [2].The corporate image means, according to another definition, "a concept that is revealed by all staff of a company in terms of the customers' impressions to be constituted as a result of the presentation submitted by 
companies about themselves" [3].

The corporate image means, on the other hand, all of the factors which put forth the targets of companies to be reached in the future, the efforts utilized for explaining the liabilities they have, and the perspectives they have both for environment and people [11].

The corporate image is also the emotional attitudes of customers related to a company. Companies shall attain, in this regard, a distinctive feature from other companies in the eyes of their customers, thanks to their sense of corporate image, and thus they shall have some advantages. It will only be possible, however, to understand the details of corporate image if the emotional attitudes of the customers as well as the logical decisions are evaluated as a whole [7].

It seems, when the specified definitions are examined accordingly, that the corporate image is related to various factors. The leading factor among these is the perceptions or ideas of people or consumers about a company. The thoughts and perceptions of people, today, can be shaped by means of advertisements and other elements which are broadcasted/ issued through various means of communication. The companies can, in this context, improve their corporate image further through relevant tools.

The image of companies is a factor which gets different comments from consumers or customers. In this regard, the corporate image contains a general sense to be revealed by all customers of a company. The needs of customers, on the other hand, ensure the corporate image to be shaped accordingly. The corporate image emerges, therefore, as a result of the opinions, thoughts, and attitudes of customers. The businesses should, in this regard, be able to utilize the thoughts and perceptions of customers accordingly during processes of production or services [4].

The goals of companies for establishing a sense of corporate image may be summarized as follows [16]:

1. Creating a sense of confidence, in the customers' eyes, for all of their products,

2. Simplifying the conditions of sales if new products are to be submitted to the market,

3. Increasing employee satisfaction and ensuring continuity of employees who work for them,

4. Ensuring that a company benefits from new potentials,

5. Increasing sales of products,

6. Employing qualified staff,

7. Having leaders who can represent a company well, and

8. Increasing the number of people who are familiar with them.

The ability of companies or institutions to survive depends, in today's conditions, on the corporate image. In this regard, the corporate image is evaluated as the unique concept reflecting the purpose for building up a company. The attitudes by which the customers, partners, and stakeholders of a company perceive a company will ensure the continuity or discontinuity of a company. The success of companies, therefore, will only be possible if they have a positive corporate image [8].

The corporate image can be evaluated as "good", "bad" or "ineffective". It is also possible that there may be many sub-levels between good image and bad image. Many factors can do harm on the image of companies. The corporate image may be damaged by bad production in some cases, by reflection of negative events in company to the people in some cases, and by bad/ineffective introduction or advertising in some other cases [15].

The corporate image will/ may change customers' perceptions about articles or services. Therefore, products of companies which have good sense of corporate image can be regarded by their customers as superior quality than the products of other companies. The companies, which cannot sell their product easily, shall be able to increase the sales of products only by increasing their corporate image. The loyalty of customers to a company goes up proportionally as a result of the increases in sales of firms with superior corporate image. In this regard, the companies can keep long-term customers. The corporate image is extremely important for companies in today's competitive environment (12).

Products and services have become more and more similar to each other in course of time. Such a state of affairs has been causing the difference between goods and services to be removed. The number of companies available in market, however, has been increasing each passing day. The conditions for competition have been growing up proportionally as the number of companies increase. The fact that the differences in terms of goods or services begin to die away makes companies use the corporate image as a competitive tool. The institutional image, in this regard, emerges as a method for dissociating companies from their competitors (12).

\section{Corporate Image in Sports Clubs}

Today, sports clubs have been carrying out their duties and forming their structures as a company. Additionally, sports clubs have been selling their different kind of sport-gears and similar products as well as trading on the stock exchange. Such conditions have become a necessity for sports clubs to attach importance to their corporate image.

It is possible to describe a sports club in the form of an association which encircles various sports branches for the young in order to encourage them to participate in sports. So, the young shall be registered as members of a club after getting approval from relevant governmental institutions [17].

Sports clubs are the establishments set up per various principles and their members, therefore, have some liabilities. Sports clubs, which possess appropriate 
facilities equipped with various instruments and tools as well as their own distinctive legal understructures, serve for professional or amateur sports branches [14].

Sports clubs have an important role for expanding the area covered by sports in society. Sports clubs are obliged, at the same time, to respond to people's desires. In this context, the survival of sports clubs depends on their ability to get various incomes [6]. Sports clubs, under these conditions, should be able to generate various revenues by prioritizing their corporate image and spend these incomes in favor of sporting activities.

\section{Method}

\section{Population and Samples}

The subjects of this research are consisted of total 372 participants.

\section{Data Collection Tool}

The descriptive scanning model was used in the study. A questionnaire was used as the data collection tool in this research. The questionnaire is comprised of two parts. The first part includes some questions about demographic information and the second part the questions about the corporate image.

Institutional Image Scale: There are 17 statements total related to the institutional image as 1 to 7 for measuring internal images perceived and 8 to 17 for measuring external images constructed. The master's thesis of Hakan Çakmak entitled, "Kurumsal İmajın Şirketin Farklı Paydaşları Tarafından Algılanışı üzerine bir Araştırma" and the study of Şemseddin Süceddinov named, "Kurumsal Kimlik, Kurumsal İmaj Oluşturma Süreci ve bir Araştırma" have been utilized for the measurements accomplished. The scale has two sub-dimensions; one is independency (freedom) and the other feedback.

\section{Data Analysis}

The data analysis for the study was accomplished by means of the SPSS 16 package program. The descriptive statistics, T-test, and Anova tests were implemented for analyzing the data obtained.

\section{Findings and Comment}

The participants were consisted of males with a percent 61.3 , females $38.7 \%, 1-25$ years old with a percent 22.6 , 26-32 years old with $37.7 \%$, 33-42 years old with $25.8 \%$, in the age of $43-50$ with $12,9 \%$, married ones with $77,4 \%$, and single ones with $22,6 \%$.
Table 1. Findings Related to Demographic Variables

\begin{tabular}{|c|c|c|}
\hline & Frequency & $\%$ \\
\hline \multicolumn{3}{|c|}{ Gender } \\
\hline Female & 144 & 38,7 \\
\hline Male & 228 & 61,3 \\
\hline Total & 372 & 100,0 \\
\hline \multicolumn{3}{|c|}{ Ages } \\
\hline $18-25$ & 84 & 22,6 \\
\hline $26-32$ & 144 & 37,7 \\
\hline $33-42$ & 96 & 25,8 \\
\hline $43-50$ & 48 & 12,9 \\
\hline Total & 372 & 100,0 \\
\hline \multicolumn{3}{|c|}{ Marital Status } \\
\hline Married & 288 & 77,4 \\
\hline Single & 84 & 22,6 \\
\hline Total & 372 & 100,0 \\
\hline
\end{tabular}

Table 2. The Correlation between Genders and Corporate Image

\begin{tabular}{|c|c|c|c|c|}
\hline & & Average & $\mathrm{t}$ & $\mathrm{p}$ \\
\hline \multirow{2}{*}{$\begin{array}{c}\text { Independency } \\
\text { (Freedom) }\end{array}$} & Female & 51,23 & \multirow{2}{*}{0,502} & 0,681 \\
\cline { 2 - 3 } & Male & 52,31 & & \multirow{2}{*}{0,400} \\
\hline \multirow{2}{*}{ Feedback } & Female & 51,63 & 0,753 \\
\cline { 2 - 3 } & Male & 52,74 & & \\
\hline
\end{tabular}

Relationship between genders and institutional image perception is evaluated, the institutional image perception does not vary depending on the gender $(p>0,05)$. Both female ones and men have the same perception about the corporate image of sports clubs.

Table 3. Relationship between Age and Institutional Image Perception

\begin{tabular}{|c|c|c|c|c|}
\hline & & Average & $\mathrm{F}$ & $\mathrm{p}$ \\
\hline \multirow{4}{*}{$\begin{array}{l}\text { Independency } \\
\text { (Freedom) }\end{array}$} & $18-25$ & 50,32 & \multirow{4}{*}{0,573} & \multirow{4}{*}{0,637} \\
\hline & $26-32$ & 51,46 & & \\
\hline & $33-42$ & 51,25 & & \\
\hline & $43-50$ & 52,69 & & \\
\hline \multirow{4}{*}{ Feedback } & $18-25$ & 50,41 & \multirow{4}{*}{0,542} & \multirow{4}{*}{0,654} \\
\hline & $26-32$ & 50,68 & & \\
\hline & $33-42$ & 52,53 & & \\
\hline & $43-50$ & 52,47 & & \\
\hline
\end{tabular}

When the correlation between age and institutional image perception is analyzed, the perception of institutional image does not differ in terms of age $(p>0,05)$. Individuals within all of the age groups have the same perception about the corporate image of sports clubs.

Relationship between marital status and institutional image perception is examined, on the other hand, the institutional image perception does not vary in terms of marital status $(p>0,05)$. Both married ones and singles have the same perception about the corporate image of sports clubs. 
Table 4. Relationship between Marital Status and Corporate Image Perception

\begin{tabular}{|c|c|c|c|c|}
\hline & & Average & $\mathrm{t}$ & $\mathrm{p}$ \\
\hline \multirow{2}{*}{$\begin{array}{l}\text { Independency } \\
\text { (Freedom) }\end{array}$} & Married & 51,42 & \multirow{2}{*}{0,822} & \multirow{2}{*}{0,442} \\
\hline & Single & 52,68 & & \\
\hline \multirow{2}{*}{ Feedback } & Married & 51,47 & \multirow{2}{*}{0,915} & \multirow{2}{*}{0,403} \\
\hline & Single & 52,36 & & \\
\hline
\end{tabular}

\section{Discussion and Conclusion}

Cinaroglu and Sahin article in 2013 has been demonstrated parallels with our work. This article also evaluated gender and age such as our article. [12]

Giray and Girisken's working about audience of Besiktas Football Club, their article also has found same result our study. [5]

Sports clubs have recently been acting like establishments and they have been building their sub-structures like companies. All of the activities performed within the body of sports clubs are carried out using specific resources. Sports clubs should, in this regard, be able to get various incomes to survive. Such a fact has been urging sports clubs to create a positive corporate image for themselves.

In this study, the corporate image perception for sports clubs was examined. According to the results of the research, the perception of sports clubs does not differ in terms of the demographic characteristics of the individuals. The fact that sports clubs have been useful for a society, as argued in the survey, increases the sense of corporate image. While individuals accept the benefits of sports clubs on society, they also increase the perception of corporate image. However, the negative news in the media about sports clubs has been causing a decrease for the perception of the institutional image of sports clubs.

\section{REFERENCES}

[1] Argenti, Paul A., (1996), "Corporate Communication as a Discipline: Toward a Definition", Corporate Communication Quarterly, Vol: 10

[2] Argenti, Paul A. and Janis Forman (2002), the Power of Corporate Communication, McGraw-Hill Companies, NY, USA.

[3] Dinçer, M. K. (2001). Personal Image, (Third Edition) Istanbul: Alfa Basım Yayım Dağıtım.
[4] Erdoğan, B. Z., Develioğlu, K., Gönüllüoğlu, S. and Ozkaya, H. (2006). "A Study on the Perception of Corporate Image by Different Stakeholders", Journal of Social Sciences, Dumlupınar University, pp. 56-76.

[5] Girişken, Y. And Giray, C. (2016). Vodafone'un Marka Kişiliği: Beşiktaş Taraftarı, Rakip Takım Taraftarları ve Takım Tutmayanların Algılarındaki Fark Üzerine Bir Araştırma. Ege Academic Review, 16(1).

[6] Göymen M. (2001), “A Corporation Model for the Institutionalization of sports clubs and Effects of it for Preventing Sports Accidents", unpublished PhD Thesis, Gazi University, Institute of Science and Technology, Ankara.

[7] Gülsoy, T. (1998). Dictionary of Advertisement Terms and Concepts. Istanbul: Adam Yayınları.

[8] Gülsünler, M. E. (2007). "A Theoretical and Practical Study on Institutional Identity Process and its Functioning" Journal of Social Sciences, p.288-294, Selçuk University.

[9] Karpat, I. (1999). Corporate Advertisement by Examples in Banking Sector, İstanbul: Yayınevi Yayıncılık.

[10] Kırıml1, C. (1993). "Brand Concept and Image Analysis of M.E.T.U. Business School: A Positioning Approach " Published Master Thesis, Institute of Social Sciences, Middle East Technical University, Ankara.

[11] Sabuncuoğlu, Z. (2004). Public Relations in Establishments, Istanbul: Aktüel Yayınları, 7th Edition.

[12] Selvi, M. S. (2007). Customer Loyalty. Ankara: Detay Yayıncilık.

[13] S. Çınaroğlu and B. Şahin. (2013). Özel Ve Kamu Hastanelerinin Algilanan Kurumsal İtibar Ve İmaj Açısından Karşılaştırılması. Uluslararası Yönetim İktisat ve İșletme Dergisi, Cilt 9, Sayı 18，2013 Int. Journal of Management Economics and Business, Vol. 9, No. 18, www.ijmeb.orgISSN:1301-4749E-ISSN:1301-8051 http://dx.doi.org/10.11122/ijmeb.2013.9.18.79

[14] Şahin HM. (2004), Dictionary of Basic Concepts on Physical Education and Sports, 2nd Edition, Nobel Yayın Dağıtım, Ankara.

[15] Taslak, S. and Akın, M. (2005). "A Research on the Factors Affecting the Image of an Organization": Yozgat Police Department", Journal of Social Sciences Institute, ss. 263-294, Erciyes University.

[16] Tasskın, E. and Sönmez, S. (2005). The Role of Public Relations in Creating Corporate Images and a Field Survey. Academic View International Refereed Social Science E-Book S.7

[17] http://tdk.gov.tr/index.php?option=com gts\&arama= gts\&guid=TDK.GTS.55644e43d5bc37.30494555 Access Date: 